\title{
Improving BMP Cost-Share Enrollment Rates: Insights from a Survey of Florida Farmers
}

\author{
Lauriane S. Yehouenou $\odot$, Kelly A. Grogan, Xiang Bi, and \\ Tatiana Borisova
}

\begin{abstract}
This paper investigates cost-share program attributes that would affect producers' willingness to enroll in a cost-share program to fund the adoption of best management practices to improve water quality and decrease water use. Through a survey administered to Florida agricultural producers, we conducted choice experiments to assess farmers' preferences for cost-share programs using five attributes: contracting agency, length of contract, annual verification process, costs included, and percent of costs covered. Results suggest that producers prefer cost-share programs with shorter contract lengths, self-monitoring, and administration by agricultural (as opposed to environmental) agencies. Our findings suggest the importance of an existing trust between the local communities and the contracting agencies for higher enrollment rates in cost share programs. Our results can inform policymakers on ways to increase enrollment rates that move towards long-term environmental goals.
\end{abstract}

Key words: best management practices, cost-share programs, choice experiment, water management, agri-environmental policy, Florida

\section{Introduction}

Water is a crucial element not only for the environment but for industries like agriculture, tourism, retail, and real estate development. Water management issues are different in Florida than they are in other states because water has historically been one of the state's most abundant natural resources (Odera et al. 2013). However, due to climate change, population growth, and land development, there is increasing pressure on water supplies and water quality. In Florida, both excessive water use and pollution contribute to impaired water quality. Basin Management Action Plans (BMAPs) have been created to address this water quality impairment. A key component of these plans is the requirement that agricultural producers adopt best management practices (BMPs). As our data will demonstrate, while most producers have adopted some BMPs, for any individual BMP, adoption rates are still low. Encouraging adoption of a more comprehensive bundle of BMPs could lead to larger impacts on water flows and water quality. Given that adoption of BMPs

University of Florida, Food and Resource Economics Department. Correspondence: Lauriane S. Yehouenou, Email: lyehouenou@ufl.edu

Agricultural and Resource Economics Review 49/2 (August 2020) 237-269

(C) The Author(s) 2020. This is an Open Access article, distributed under the terms of the Creative

Commons Attribution licence (http://creativecommons.org/licenses/by/4.0/), which permits unrestricted re-use, distribution, and reproduction in any medium, provided the original work is 
have positive externalities that growers likely do not incorporate into their decision-making process, cost-share programs are one possible way to incentivize the adoption of BMPs. Despite the existence of cost-share programs, adoption of BMPs is still relatively low, raising the question of how such programs could be designed to increase enrollment and increase adoption of BMPs. This article seeks to answer this question.

Using a survey of Florida agricultural producers, this article explores how cost-share program attributes could affect enrollment and consequently adoption of BMPs. We focus on four BMPs that were identified by the Florida Department of Environmental Protection (FDEP) and the Florida Department of Agriculture and Consumer Services (FDACS) as key practices to conserve water and reduce nutrient pollution from Florida agricultural producers. These practices include: the use of soil moisture sensors to determine when irrigation water is needed; annual soil and crop tissue testing for nitrogen, phosphorous, and potassium to more accurately assess fertilizer needs; and the use of UF/IFAS's nutrient application recommendations to reduce nutrient runoff. This research provides insights on how to best design costshare programs that meet producers' needs and preferences in order to increase participation rates. Our findings suggest that farmers prefer costshare programs that have shorter contract lengths, that are self-monitoring, and that are administered by state-level agricultural agencies, which are more likely to have Florida-specific interests.

The next section provides background on Florida water management. The third section summarizes previous literature. The fourth section explains the underlying theoretical framework of the study. The data section describes the design and application of the choice experiment. This is followed by the empirical methods. The empirical results follow, and the last section presents conclusions.

\section{Florida Water Management}

Florida is one of the top 12 U.S. states for irrigated agricultural land acreage (Schaible and Aillery 2012), it is fourth among U.S. states in water withdrawals for public supply (Dieter et al. 2018; Marella 2014), and it has a significant tourism industry dependent on water resources. The Floridan aquifer underlying the state supplies drinking water for nearly 10 million people and supports agricultural and recreational needs (Marella and Berndt 2005). However, due to climate change, population growth, and land development, there is increasing pressure on water supplies. The total withdrawal of water in Florida accounted for 15,319 million gallons per day (Mgal/d) in 2015; of which 5,721 Mgal/d were freshwater (Marella and Dixon 2018). In 2015, 46 percent of the total freshwater withdrawals were used for public supply, including tourism, landscape irrigation of lawns and golf courses, and recreation, followed closely by self-supplied water for agricultural production (40\%) (Bellino 2017; Marella and Dixon 2018). 
Interestingly, these sectors are also the most affected by reductions in water levels and water quality impairments, given their dependency on freshwater resources. Given a finite supply of water, there is direct competition between extractive water users, such as agricultural producers and households, and in-stream water uses, such as aquatic ecosystem support and tourism and recreation.

In Florida, agricultural lands total about 8 million acres, of which 24 percent are irrigated for crops. Forecasts through 2040 suggest a four percent increase in irrigated acreage associated with a 14 percent increase in water use statewide (FDACS 2017). In addition, the plethora of surface water resources and vast freshwater aquifers of the state are imperiled by nutrient pollution (from both agricultural and non-agricultural sources) and increasing water withdrawals through the state by a variety of water users. As a result, large areas of the state are classified as "water resource caution areas" (FDEP 2011). The forecast of water use in these areas suggests that they will undergo severe water supply problems within the next 20 years (FDEP 2011).

The state of Florida utilizes BMAPs to set goals by industry that, if met, would enable the basins to meet established Total Maximum Daily Loads (TMDLs) which set pollution loading limits for specific bodies of water. BMAPs are the "blueprints" for pollution reduction to improve water quality. They include a "set of strategies such as permit limits on wastewater facilities, urban and agricultural best management practices, conservation programs, financial assistance and revenue generating activities" (FDEP 2011). Basins that include significant agricultural production set target BMP adoption rates as part of their BMAPs (FDEP 2018). BMPs include specific practices designed to limit the amount of fertilizers, pesticides, animal waste, and other pollutants entering water resources from agricultural production and practices in order to reduce total water used per unit of production.

\section{Previous Literature}

Relevant literature includes studies using choice experiments to study the adoption of various agricultural or land management practices, studies analyzing the adoption of agricultural best management practices in general, and most relevant for our work, studies analyzing best management practices pertaining to water management.

Many previous studies have used choice experiments to analyze willingness to pay for environmental attributes or willingness to accept and adopt sustainable practices. Studies vary from valuing wetland attributes for recreational purposes to improved quality for domestic water demand (Alcon et al. 2014; Barton and Bergland 2010). Choice experiments have also been used to analyze the adoption of sustainable practices in forestry and risk management in agriculture. Horne (2006) investigates factors that affect forest owners' willingness to accept a contract for biodiversity conservation in Finland. She uses five attributes: the initiator of the conservation contract; 
the restrictions on forest use; the compensation per hectare annually; the duration of the contract; and the cancellation policy. Her findings suggest that respondents prefer to be the initiator of the contracts rather than having them imposed on them by a forest organization, environmental organization, or conservation trust. They also prefer to conserve small patches of forest under short contracts with the flexibility to opt out from the contract at their will. Looking into the Chinese forestry sector, Qin, Carlsson, and Xu (2009) find that shorter contract lengths, shorter wait times before harvest, and lower risk of contract termination increase the farmers' perceived value of a forestland contract. With regard to risk management in agriculture, Mercadé et al. (2009) investigate farmers' preferences for crop insurance in Catalonia. Lower insurance cost, increased types of risk covered, and lower minimum thresholds for payment were the main factors associated with increased probability of adoption.

A large literature considers adoption of best management practices. Two meta-analyses summarize this extensive literature, with one focusing on studies prior to 2008 (Prokopy et al. 2008) and the second focusing on studies published between 2008 to 2017 (Liu, Bruins, and Heberling 2018). Common factors associated with adoption include farmers' characteristics (income, social networks, demographics, knowledge, risk preferences, and environmental awareness), farm characteristics (land tenure, farm size, fertility, slope, altitude, proximity to urban areas), the characteristics of the best management practices (cost-effectiveness, time requirement, ease of use, flexibility, observability, potential for spatial and temporal spillover effects) (Prokopy et al. 2008, Liu, Bruins, and Heberling 2018). Among other points, the authors suggest the understanding of the decision-making process through the analysis of farmers' preferences is an area in need of more research. Therefore, one goal of this article is to fill this void by investigating the farmers' preferred cost-share program attributes for water management BMPs in Florida.

Previous work utilizing choice experiments for water management options are most pertinent for our study. Alcon et al. (2014) explore farmers' willingness to pay a premium for irrigation water in Spain. Their results suggest that a guaranteed quantity of water supplied increases a farmer's willingness to pay. Interestingly, willingness to pay based on water source varies by region. In regions with ample water supply, retaining their current water source is associated with higher willingness to pay, whereas in regions with water shortages, utilizing new water sources increases willingness to pay. In South Africa, Saldias et al. (2016) attempt to understand farmers' preferences for wastewater reuse in agricultural irrigation. Their findings show that respondents are willing to adopt reclaimed wastewater if (i) the water quality is guaranteed, (ii) there are low restrictions on water usage for irrigation, and (iii) the water service providers are privately managed.

Despite the vast literature on adoption of environmentally friendly practices, to the best of our knowledge, no work has considered the effects of the 
implementing agency on probability of adoption. Within most states, implementation of an agri-environmental program could be done through either the department of agriculture or the department of environmental protection. Our results suggest the former will lead to increased adoption relative to the latter. Similarly, allowing states to implement programs as opposed to federal implementation could increase adoption.

\section{Theorical Framework and Empirical Model}

We model producer decisions using random utility theory (McFadden 1974), which implies that every producer is a rational decision-maker $i$ maximizing utility, $U_{i}$, based on his or her choice set of available practices. Mathematically, utility received from choosing practice $j$ will be represented as:

$$
U_{i j}=V_{i j}+\varepsilon_{i j}
$$

where $V_{i j}$ represents the deterministic component of expected utility, while $\varepsilon_{i j}$ is the random component of utility. In an agricultural context, utility is largely determined by profit, but as our results will show, growers also have preferences for things like agencies with whom they prefer to work, making a utility a more all-encompassing metric to use.

The functional form for the utility can be specified as:

$$
U_{i j}=\beta^{\prime} X_{i j}+\delta^{\prime} Z_{i}+\varepsilon_{i j}
$$

where $X_{i j}$ is a vector of observed alternative-specific attributes, and $Z_{i}$ is a vector of producer and farm characteristics. Based on previous literature, $Z_{i}$ includes demographic characteristics of the producer (age, experience, gender, education, income), farm attributes (acreage, crop type, organic certification status), experience with previous cost-share programs, and perceptions of alternative practices. $\beta$ and $\delta$ are assumed to be constant across respondents, while the error term is assumed to be an independently and identically distributed Gumbel distribution.

Producer $i$ will choose an alternative $j$ over alternative $k$ if $U_{i j}>U_{i k}$. Considering alternatives $j$ and $k$, and assuming the random component in the utility function follows the Type 1 extreme value distribution (i.e., the Gumbel maximum distribution), the probability of choosing alternative $j$ for individual $i$ is given by:

$$
P_{i j}=\frac{e^{V_{i j}}}{e^{V_{i j}}+e^{V_{i k}}}
$$

We use the conditional logit to estimate parameters $\beta$ and $\delta$. This model assumes homogeneous preferences across respondents and the independence 
from irrelevant alternatives (IIA) property, which suggests that the relative probabilities of two options being chosen are unaffected by introduction or removal of other alternatives. If the IIA property is violated, the CL estimates will be biased, and we must use a discrete choice model that does not require the IIA property, like the random parameter logit (RPL)-also known as the Mixed Logit (ML) model. We test for the IIA property of the CL model using the test of Hausman and McFadden.

\section{Data}

\section{Choice experiment design}

The survey included a choice experiment with a fractional factorial design with a D-efficiency of 97.57. This design included 18 choice sets blocked into three groups of six. Each respondent received one block. A design with full efficiency would have required 36 choice sets. This option was discarded out of concern for survey length and sample size. For each set, the respondent was asked to choose which of two plans (A or B) in which they would hypothetically enroll to cover a portion of the costs of adopting soil moisture sensors, annual crop and soil tissue testing, and use of UF/IFAS nutrient recommendations. The respondent also had the option of rejecting both plans (Figure 1).

The cost-shares varied along five attributes: the cost-share contracting agency, the duration of the contract, the type of costs included in the costshare, the monitoring method used to verify the producer's practices, and the percent of costs covered by the agency (Table 1). For contracting agencies, we consider a state-level agricultural agency (Florida Department of Agriculture and Consumer Services or FDACS), a state-level environmentally focused agency (Florida Department of Environmental Protection or FDEP), and a federal-level agricultural agency (United States Department of Agriculture or USDA). We hypothesize that producers may have a preference for agriculture agencies over environmental agencies and a preference for local over non-local. The duration of the contract has three levels in our choice experiment: 5, 10, and 15 years. According to previous literature, we hypothesize that respondents will be less likely to choose longer contracts. For the verification process, we consider self-reporting by producers or onfarm visits by the contracting agency's agents. Agricultural producers tend to value privacy, so we hypothesize that self-reporting would be preferred to on-farm visits. The fourth attribute is the costs included in the program. We consider two options: covering both the initial investment (primarily soil moisture sensor installation) and the annual soil and tissue testing costs, or covering only the initial investment. In the latter case, the annual testing costs will be paid entirely by the producer. Given the high cost of initial investments, we are uncertain, ex ante, if growers will prefer subsidies for 
12. Each box below represents two hypothetical cost share programs for practices adopted to produce the product listed in question 5 . For all boxes, the agreement would be for the adoption of:

- Soil moisture sensors used to determine irrigation scheduling

- Annual soil testing for $\mathrm{N}, \mathrm{P}$, and $\mathrm{K}$

- Annual crop tissue testing for $\mathrm{N}, \mathrm{P}$, and $\mathrm{K}$

- Use of information from the soil and tissue testing to follow UF/IFAS nutrient application recommendations

The cost share would only cover the adoption of practices not currently in use on your farm for the production of the crop listed in question 5. Each program varies in terms of its characteristics, which may affect your likelihood of enrolling in the program. For each box, please indicate which plan you would be likely to choose if offered to you. You can also indicate that you would not enroll in either plan.

If you currently use all four of the practices listed above, please check the box below and continue to question 11 .

I already use soil sensors, soil testing, and tissue testing, and I follow UF/IFAS nutrient recommendations.

12.a. Please indicate if you would enroll in Plan A, Plan B, or neither plan.

\begin{tabular}{|c|c|c|c|}
\hline Program Characteristics & Plan A & Plan B & \multirow{6}{*}{$\begin{array}{c}\text { I would } \\
\text { not enroll } \\
\text { in either } \\
\text { plan. }\end{array}$} \\
\hline Contracting Agency & FDACS & FDACS & \\
\hline Length of Contract (years) & 10 & 15 & \\
\hline Annual Verification Process & On-farm visit & Self-reported & \\
\hline Costs Included in Cost Share & $\begin{array}{l}\text { Initial investment } \\
\text { only }\end{array}$ & $\begin{array}{l}\text { Initial investment }+ \\
\text { annual testing costs }\end{array}$ & \\
\hline Percent of Costs Covered & $70 \%$ & $50 \%$ & \\
\hline Preferred Option: & $\square$ & $\square$ & $\square$ \\
\hline
\end{tabular}

\section{Figure 1. Choice Experiment Instructions and Example Choice Set}

annual investment costs over just the initial investment. Finally, we consider three levels of cost-share: 30 percent, 50 percent, and 70 percent of incurred costs, intuitively hypothesizing that higher subsidies should induce higher hypothetical enrollment rates. Respondents were not given costs for practices because these would vary by crop and region. For example, the number of soil moisture sensors required depends on the heterogeneity of soil type and topography within a farmer's operation (Zotarelli, Dukes, and Paranhos 2013), and their cost can vary substantially depending on the degree of functionality and compatibility with other equipment like automated irrigation systems desired by the producer. This variation in cost does introduce uncertainty about costs incurred by individual respondents. As 
Table 1. Attributes and Levels of the Choice Experiment

\begin{tabular}{ll}
\hline Attributes & \multicolumn{1}{c}{ Levels } \\
\hline Contracting Agency & $\begin{array}{l}\text { Florida Department of Agriculture and Consumer } \\
\text { Services (FDACS) } \\
\text { Florida Department of Environmental Protection } \\
\text { (FDEP) } \\
\text { United States Department of Agriculture (USDA) } \\
\text { 5; 10; } 15\end{array}$ \\
Length of Contract (years) & $\begin{array}{l}\text { Self-reported; On-farm visit } \\
\text { Annual Verification Process }\end{array}$ \\
Costs Included & testing costs \\
Percent of costs covered & $30 \% ; 50 \% ; 70 \%$ \\
\hline
\end{tabular}

such, we avoid converting model coefficients into measures of willingness to accept for cost-share attributes.

\section{Choice experiment data collection}

The survey was conducted via mail following Dillman's method during the summer of 2018. Due to budget limitations, we did not provide incentives to participants. The mailing targeted all farmers who are currently enrolled in the FDACS BMP program. Consequently, these farmers have adopted at least one BMP, but the vast majority have not yet adopted all key practices. This sample was chosen because it was the largest mailing list of growers available. These are also growers who have demonstrated an interest in adopting BMPs and working with FDACS to do so. These growers are the most likely to enroll in future cost-share programs. A total of 4,279 surveys were distributed. Five hundred forty-one completed surveys were received, resulting in a response rate of $12.6 \%$. This falls within the reported range $(8.1 \%$ to $15 \%)$ of response rates for Florida agricultural producers found in the literature across a range of topics, including both environmental and production-oriented surveys (Kreye, Pienaar, and Adams 2017; Milleson, Shwiff, and Avery 2006; Paxton et al. 2011; van Dijl, Grogan, and Borisova 2015).

The summary statistics of the sample are presented in Table 2. Most of the respondents are male (84\%) with an average age of 62 years old. While the average age is similar to that found in the USDA Census of Agriculture (2017) for Florida, our respondents include a smaller proportion of females than the state overall. Collectively, the individuals surveyed have substantial experience in the agriculture industry, which is reflected by an average of 27 years of experience among the respondents. Comparison data are not directly available, but about 73 percent of Florida farmers report at least 11 years of 
Table 2. Summary Statistics

\begin{tabular}{|c|c|c|c|c|c|}
\hline \multirow[b]{2}{*}{ Variables } & \multirow{2}{*}{$\begin{array}{c}\text { Mean/\% } \\
\text { FDACS/ } \\
\text { Census } \\
\text { Data }\end{array}$} & \multicolumn{4}{|c|}{ Respondents } \\
\hline & & Mean & S.D. & Min & Max \\
\hline \multicolumn{6}{|l|}{ Respondent characteristics ${ }^{\mathbf{a}}$} \\
\hline Total acres & 201 & 665.81 & 1958.42 & 0 & 24500 \\
\hline Age & 58.9 & 61.57 & 11.31 & 27 & 90 \\
\hline Years of experience & $11+$ & 27.00 & 14.83 & 1 & 80 \\
\hline Gender (\% male) & $63.8 \%$ & $84 \%$ & & & \\
\hline $\begin{array}{l}\text { Education (\% with university } \\
\text { degree and above) }\end{array}$ & & $55.40 \%$ & & & \\
\hline $\begin{array}{l}\text { Retirement plan (\% planning to } \\
\text { pass on farm to family member) }\end{array}$ & & $63.33 \%$ & & & \\
\hline Organic (\% certified organic farms) & & $3.41 \%$ & & & \\
\hline $\begin{array}{l}\text { Income (\% with income greater } \\
\text { than or equal to } \$ 100,000 \text { ) }\end{array}$ & & $50.94 \%$ & & & \\
\hline \multicolumn{6}{|l|}{ Primary production } \\
\hline Cattle & & $33.6 \%$ & 0.473 & & \\
\hline Citrus & & $12.5 \%$ & 0.331 & & \\
\hline Ornamental plants & & $9.8 \%$ & 0.298 & & \\
\hline Hay & & $8.9 \%$ & 0.285 & & \\
\hline \multicolumn{6}{|l|}{ Irrigation type used $^{b}$} \\
\hline No irrigation & $76.4 \%$ & $46.5 \%$ & 0.499 & & \\
\hline Micro-irrigation & $24.6 \%$ & $28.5 \%$ & 0.452 & & \\
\hline Sprinkler & $34.6 \%$ & $26.0 \%$ & 0.439 & & \\
\hline Other irrigation & - & $07.5 \%$ & 0.264 & & \\
\hline Seepage & $3.74 \%$ & $5.4 \%$ & 0.226 & & \\
\hline Sample size & & 541 & & & \\
\hline
\end{tabular}

${ }^{\mathrm{a}}$ Comparison data obtained from USDA, 2017.

${ }^{\mathrm{b}}$ Comparison data obtained from USDA, 2018.

experience in the Census of Agriculture (USDA 2017). The average respondent farm size is about 666 acres, relative to an average size of 201 acres reported in the Census (2017). Our sample includes several large cattle ranches that skew our acreage distribution. Our results may be less applicable to smaller farms. However, from an environmental perspective, large farms will have a larger impact, so this sample selection bias is not as worrisome as a bias towards small farms would have been. 
Our respondents primarily raise/grow cattle (33.6\% of the respondents), citrus $(12.5 \%)$, ornamentals plants $(9.8 \%)$, and hay $(8.9 \%)$. The most used irrigation type is micro-irrigation (28.5\%), followed by overhead sprinklers $(26 \%)$. Almost half of the respondents $(47 \%)$ do not use any irrigation system. The Census of Agriculture reports that $76.4 \%$ of Florida operations do not use irrigation (USDA 2017). This suggests that many non-irrigating producers chose not to complete the survey. As with farm size, the direction of this selection bias is less troubling than the reverse because we are most interested in water conservation behaviors, which is most relevant for farms with irrigation systems.

Over 60 percent of farmers plan to pass on their farms to a family member for continued agricultural use upon retirement. Fifty-one percent of the sample report an annual income above $\$ 100,000$. Table 3 presents the participation rate in cost-share programs for the respondents. Except for the Environmental Quality Incentives Program, local or state agency programs have higher participation than federal agency programs.

\section{Results}

Respondents were asked to indicate which of 27 specific BMPs they had adopted. They were then asked to identify which of these practices were their highest priorities for adoption in the next three years. Table 4 summarizes the results for the four practices of most interest. Annual soil testing is currently the most adopted practice (62.4\%). It is also the mostmentioned highest priority for future adoption. Use of soil moisture sensors is the least frequently adopted of the practices $(12.0 \%)$ but the second mostmentioned priority for the next three years. Tissue testing ranks low in producers' priorities for future adoption. Lastly, only 5.4 percent of the respondents in the sample have adopted all four key practices.

Respondents were then asked about barriers to adoption and were allowed to provide more than one reason. Economic factors are the primary barriers, with over 65 percent of the respondents stating the costs of installation prevented adoption while almost 25 percent could not finance installation (Table 5).

Table 6 presents the summary statistics of respondents' answers to the choice experiments. Across all choice experiments seen, respondents chose either Plan A or Plan B in 33.33 percent of experiments. Respondents chose "I would not enroll in either plan" in 66.67 percent of choice experiments. Across all six experiments faced by the respondents, 43.62 percent of respondents always chose "I would not enroll in either plan."

Table 7 contains the coefficient estimates and the marginal effects for the cost-share program attributes without any case-specific variables (columns 2 and 3) and with case-specific variables like respondent characteristics (columns 4 and 5). Given that each respondent could choose Plan A, Plan B, or neither plan, there are two marginal effects of each attribute on selection of Plan A or Plan B relative to choosing neither plan. 
Table 3. Participation in Cost-Share Programs $(\mathrm{N}=541)$

\begin{tabular}{|c|c|}
\hline Programs & Participation rates \\
\hline \multicolumn{2}{|c|}{ USDA-Farm Service Agency (FSA) Programs } \\
\hline Conservation Reserve Program & $6.8 \%$ \\
\hline Conservation Reserve Enhancement Program & $3.8 \%$ \\
\hline \multicolumn{2}{|c|}{ USDA-Natural Resources Conservation Service (NRCS) Programs } \\
\hline Environmental Quality Incentives Program & $22.9 \%$ \\
\hline Conservation Plans & $11.2 \%$ \\
\hline Wildlife Habitat Incentives Program & $4.6 \%$ \\
\hline Wetlands Reserve Program & $1.9 \%$ \\
\hline Conservation Stewardship Program & $1.9 \%$ \\
\hline \multicolumn{2}{|c|}{ State or Local Agencies Programs } \\
\hline BMP cost-share through FDACS & $32.4 \%$ \\
\hline Water Management District & $17.4 \%$ \\
\hline Soil and Water Conservation District & $14.4 \%$ \\
\hline
\end{tabular}

Table 4. Current Adoption Rates and Percent of Respondents Who Plan To Adopt Practice in the Next Three Years $(N=541)$

\begin{tabular}{lcc}
\hline Practices & Current adoption rates & Future adoption rates \\
\hline Annual soil testing & $62.4 \%$ & $30.3 \%$ \\
UF-IFAS nutrient recommendations & $32.9 \%$ & $12.6 \%$ \\
Tissue testing & $17.7 \%$ & $11.5 \%$ \\
Soil moisture sensors & $12.0 \%$ & $18.1 \%$ \\
\hline
\end{tabular}

Table 5. Percent of Respondents Reporting Factor as Preventing Adoption of BMPs $(\mathrm{N}=541)$

\begin{tabular}{lc}
\hline Factors & Percentage of respondents \\
\hline Costs of installation & $65.7 \%$ \\
Cannot finance & $25.7 \%$ \\
Other reasons & $15.5 \%$ \\
Might leave the ag. industry & $13.4 \%$ \\
Risk of reduced yield & $6.5 \%$ \\
Adoption takes too much time & $3.6 \%$ \\
Uncertainty about water availability in the future & $3.6 \%$ \\
\hline
\end{tabular}


Table 6. Respondents' Answers to Choice Experiments $(N=541)$

\begin{tabular}{lc}
\hline Enrollment Choice & Percentage \\
\hline Selected Plan (either A or B) & $33.33 \%$ \\
Selected Neither Plan & $66.67 \%$ \\
\% of respondents who never chose a plan & $43.62 \%$ \\
\hline
\end{tabular}

All cost-share program attribute coefficients are statistically significant in both specifications. When considering only cost-share attributes, respondents are 1.52.1 percent more likely to adopt plans implemented by FDACS compared to USDA. A third of respondents already participate in cost-share programs administered by FDACS. FDACS also has several programs that provide support directly to Florida farmers, including the "Fresh from Florida" marketing campaign as well as awards to recognize high-performing individuals. Consequently, FDACS is viewed as a trustworthy organization with which growers might be more willing to interact than a federal agency that is further removed from Florida-specific interests. Previous literature has also shown that building the trust of farmers is critical for conservation practice adoption (Liu et al., 2018). On the other hand, producers are 2.4-3.3 percent less likely to adopt a cost-share plan provided by the FDEP compared to the USDA. Moreover, for each additional year of contract length, respondents are 0.6-0.9 percent less likely to select the contract. This could be explained by the older age of the average respondent, who would have a lower incentive to enter into a long-term contract with retirement approaching. On-farm visits for the annual verification process is associated with a $0.5-0.7$ percent decrease in likelihood of adoption relative to programs with self-reporting only. Respondents are 2.2-2.8 percent more likely to prefer a program that provides both initial investment and annual testing costs compared to a program only covering the initial investment. Moreover, for each additional percentage point of cost sharing, respondents are $0.4-0.5$ percent more likely to adopt the program.

With respondents' characteristics included in the model, the attributes' coefficient signs remain unchanged. Marginal effects remain unchanged for the attribute "percent of costs covered" but slightly change quantitatively for the remaining attributes with the highest change reported for the on-farm visit attribute (1.4-1.8\% less likely to adopt if farm visits are featured in the contract). Written comments from respondents expressing their discomfort with on-farm visits as a verification process can explain the marginal effect observed for that attribute.

Table 7 also presents the conditional logit coefficients and marginal effects for the respondents' characteristics. A Wald test was conducted to test whether the coefficients for the respondent characteristics variables are simultaneously equal to zero. Results from the test suggest that these variables are jointly significant. Although the results are reported for two options in a given choice experiment, 
Table 7. Conditional Logit and Marginal Effects Estimates for Cost-Share Program Adoption ( $=541)$

\begin{tabular}{|c|c|c|c|c|c|c|}
\hline \multirow[b]{2}{*}{ Attributes } & \multicolumn{2}{|c|}{ (1) Cost share attributes only } & \multicolumn{4}{|c|}{ (2) Cost share + Respondent's characteristics } \\
\hline & Coeff. & Marg. effects & \multicolumn{2}{|c|}{ Coeff. } & \multicolumn{2}{|c|}{ Marg. effects } \\
\hline FDACS & $\begin{array}{l}0.169^{* *} \\
(0.081)\end{array}$ & $\begin{array}{c}0.015,0.021^{* *} \\
(0.008,0.011)\end{array}$ & \multicolumn{2}{|c|}{$\begin{array}{l}0.201^{* *} \\
(0.098)\end{array}$} & \multicolumn{2}{|c|}{$\begin{array}{c}0.020,0.026^{* * *} \\
(0.010,0.013)\end{array}$} \\
\hline FDEP & $\begin{array}{c}-0.273^{* *} \\
(0.112)\end{array}$ & $\begin{array}{c}-0.033,-0.024^{* *} \\
(0.010,0.013)\end{array}$ & \multicolumn{2}{|c|}{$\begin{array}{c}-0.200^{*} \\
(0.127)\end{array}$} & \multicolumn{2}{|c|}{$\begin{array}{c}0.019,0.025^{*} \\
(0.012,0.015)\end{array}$} \\
\hline Length of contract (years) & $\begin{array}{c}-0.069^{* * *} \\
(0.010)\end{array}$ & $\begin{array}{c}-0.009,-0.006^{* * *} \\
(0.0009,0.001)\end{array}$ & \multicolumn{2}{|c|}{$\begin{array}{c}-0.076^{* * *} \\
(0.012)\end{array}$} & \multicolumn{2}{|c|}{$\begin{array}{c}-0.010,-0.007^{* * *} \\
(0.001,0.002)\end{array}$} \\
\hline On-farm visit & $\begin{array}{r}-0.055^{*} \\
(0.081)\end{array}$ & $\begin{array}{r}-0.007,-0.005 \\
(0.007,0.010)\end{array}$ & \multicolumn{2}{|c|}{$\begin{array}{l}-0.140^{*} \\
(0.093)\end{array}$} & \multicolumn{2}{|c|}{$\begin{array}{c}-0.018,-0.014^{*} \\
(0.009,0.012)\end{array}$} \\
\hline Initial + Annual Costs & $\begin{array}{l}0.161^{* *} \\
(0.077)\end{array}$ & $\begin{array}{c}0.015,0.020^{* *} \\
(0.007,0.009)\end{array}$ & \multicolumn{2}{|c|}{$\begin{array}{c}0.220^{* * *} \\
(0.088)\end{array}$} & \multicolumn{2}{|c|}{$\begin{array}{c}0.022,0.028^{* * *} \\
(0.009,0.011)\end{array}$} \\
\hline Percent of costs covered & $\begin{array}{l}0.039 * * * \\
(0.002)\end{array}$ & $\begin{array}{l}0.004,0.005^{* * *} \\
(0.0004,0.006)\end{array}$ & \multicolumn{2}{|c|}{$\begin{array}{c}0.040^{* * *} \\
(0.003)\end{array}$} & \multicolumn{2}{|c|}{$\begin{array}{c}0.004,0.005^{* * *} \\
(0.0004,0.0005)\end{array}$} \\
\hline \multirow[t]{2}{*}{ Respondents' characteristics } & & & \multicolumn{2}{|c|}{ Plan A } & \multicolumn{2}{|c|}{ Plan B } \\
\hline & & & Coeff. & Marg. effects & Coeff. & Marg. effects \\
\hline Acreage (100s) & & & $\begin{array}{l}0.007 \\
(0.009)\end{array}$ & $\begin{array}{l}0.0008 \\
(0.001)\end{array}$ & $\begin{array}{l}0.004 \\
(0.008)\end{array}$ & $\begin{array}{c}0.0002 \\
(0.0007)\end{array}$ \\
\hline Gender & & & $\begin{array}{c}-0.732^{* *} \\
(0.347)\end{array}$ & $\begin{array}{c}-0.073^{* * *} \\
(0.028)\end{array}$ & $\begin{array}{l}-0.330 \\
(0.318)\end{array}$ & $\begin{array}{c}-0.021 \\
(0.024)\end{array}$ \\
\hline Age & & & $\begin{array}{c}-0.026^{* * *} \\
(0.013)\end{array}$ & $\begin{array}{c}-0.003^{* * *} \\
(0.001)\end{array}$ & $\begin{array}{c}-0.031^{* * *} \\
(0.011)\end{array}$ & $\begin{array}{c}-0.003^{* * *} \\
(0.0009)\end{array}$ \\
\hline Education & & & $\begin{array}{l}0.423^{* *} \\
(0.216)\end{array}$ & $\begin{array}{l}0.049^{* *} \\
(0.025)\end{array}$ & $\begin{array}{l}0.232 \\
(0.210)\end{array}$ & $\begin{array}{l}0.015 \\
(0.018)\end{array}$ \\
\hline Income & & & $\begin{array}{l}0.091 \\
(0.233) \\
\end{array}$ & $\begin{array}{l}0.009 \\
(0.027)\end{array}$ & $\begin{array}{l}0.168 \\
(0.234)\end{array}$ & $\begin{array}{l}0.015 \\
(0.020) \\
\end{array}$ \\
\hline
\end{tabular}




\section{Table 7. Continued}

\section{Respondents' characteristics}

Years of experience

Organic

Log likelihood

AIC

BIC
Plan A

Coeff.

$-0.018^{*}$

(0.010)

$0.836^{*}$

$(0.465)$

$-2356.109$

4728.219

4785.689
Plan B

Marg. effects

$-0.002^{*}$

(0.001)

$0.099 * *$

(0.052)

$-1740.927$

3525.854

3677.088

*** $1 \%$ significance level, $* * 5 \%$ significance level, $* 10 \%$ significance level with two-tailed tests.

Robust standard errors reported in parentheses. Range of marginal effects are provided for each attribute. For contracting agency, USDA is the base for the FDACS and FDEP marginal effects. 
namely, Plan A and Plan B, we discuss the overall effect of each of the respondents' characteristics on the probability of adopting a cost-share program. Female respondents are 7.3 percent less likely to enroll in cost-share programs. Older farmers are less likely to enroll, with a 0.3 percent decrease in their likelihood of adoption with each additional year of age. Likewise, each additional year of experience is associated with a 0.2 percent decrease in the probability of adoption. In contrast, education and organic certification have a positive effect on the enrollment in cost-share programs, which translates into a 4.9 percent increase for respondents with a college degree relative to those without a college degree and a 9.9 percent increase for owners of certified organic farms relative to conventional farm owners.

A third specification includes a broader range of respondent and farm characteristics. Table 8 presents the results. To determine the entire array of farm characteristics to include, variables included were tested by thematic group to determine which variables should be included in the model. Table 8 includes all variable groups for which the Wald test determined that at least one coefficient was different from zero. In this specification, all cost-share attributes have the same qualitative results as previously discussed with similar marginal effects.

Considering farm characteristics, respondents who already participate in state-level cost-share programs are six percent more likely to enroll in the hypothetical cost-share program compared to those who do not. This implies that farmers would view additional cost-share programs as complementary to their current cost-share programs, and not substitutes. Not surprisingly, producers' plans to adopt the key practices in the future affect their stated hypothetical enrollment. Producers who indicated that they planned to adopt soil moisture sensors in the next three years were 10.4 percent more likely to adopt the hypothetical cost-share program while those planning to start using annual soil testing have a 4.4 percent decrease associated with their likelihood of selecting such a program. This latter counterintuitive result can be explained by the fact that soil moisture sensors are relatively expensive while annual soil testing is relatively inexpensive; most farmers would not have much difficulty covering testing costs without having to commit to an entire bundle of practices. Producers who plan to adopt UF-IFAS nutrient recommendations have a 5.5 percent increase in their likelihood of adopting a cost-share program. Intuitively, respondents who have not previously adopted BMPs because they believe they might leave the agriculture industry are about eight percent less likely to select a cost-share program.

The independence of irrelevant alternatives (IIA) property is the main underlying assumption in the CL model. In our choice experiment, for each choice set, respondents could choose between Plan A, Plan B, and a third option of selecting neither plan (Figure 1). So, under IIA, we expect no systematic change in the coefficients if we exclude any plan from the model. To test the IIA assumption, the Hausman and McFadden test was performed on the full model specification. The results are presented in Table 9. Based 
Table 8. Conditional Logit and Marginal Effects for Cost-Share Program Adoption, Full Model (N = 541)

\begin{tabular}{|c|c|c|c|c|}
\hline Attributes & \multicolumn{2}{|c|}{ Coefficients } & \multicolumn{2}{|c|}{ Marginal effects } \\
\hline FDACS & \multicolumn{2}{|c|}{$\begin{array}{l}0.191^{* *} \\
(0.101)\end{array}$} & \multicolumn{2}{|c|}{$\begin{array}{c}0.018,0.027^{*} \\
(0.011,0.016)\end{array}$} \\
\hline FDEP & \multicolumn{2}{|c|}{$\begin{array}{c}-0.363^{* * *} \\
(0.139)\end{array}$} & \multicolumn{2}{|c|}{$\begin{array}{c}-0.047,-0.032^{* * *} \\
(0.012,0.018)\end{array}$} \\
\hline Length of contract (years) & \multicolumn{2}{|c|}{$\begin{array}{c}-0.081^{* * *} \\
(0.013)\end{array}$} & \multicolumn{2}{|c|}{$\begin{array}{c}-0.011,-0.007^{* * *} \\
(0.001,0.002)\end{array}$} \\
\hline On-farm visit & \multicolumn{2}{|c|}{$\begin{array}{c}-0.139^{*} \\
(0.103)\end{array}$} & \multicolumn{2}{|c|}{$\begin{array}{c}-0.019,-0.013^{*} \\
(0.010,0.014)\end{array}$} \\
\hline Initial + Annual Costs & \multicolumn{2}{|c|}{$\begin{array}{l}0.156^{*} \\
(0.095)\end{array}$} & \multicolumn{2}{|c|}{$\begin{array}{c}0.015,0.021^{*} \\
(0.009,0.013)\end{array}$} \\
\hline \multirow[t]{3}{*}{ Percent of costs covered } & \multicolumn{2}{|c|}{$\begin{array}{c}0.044^{* * *} \\
(0.003)\end{array}$} & \multicolumn{2}{|c|}{$\begin{array}{c}0.004,0.006^{* * *} \\
(0.0004,0.0006)\end{array}$} \\
\hline & \multicolumn{2}{|c|}{ Plan A } & \multicolumn{2}{|c|}{ Plan B } \\
\hline & Coefficients & Marginal effects & Coefficients & Marginal effects \\
\hline Acreage (100s) & $\begin{array}{l}-0.001 \\
(0.010)\end{array}$ & $\begin{array}{c}0.002 \\
(0.001)\end{array}$ & $\begin{array}{c}0.010 \\
(0.010)\end{array}$ & $\begin{array}{l}-0.001 \\
(0.0008)\end{array}$ \\
\hline Gender & $\begin{array}{l}-0.456 \\
(0.393)\end{array}$ & $\begin{array}{l}-0.054 \\
(0.039)\end{array}$ & $\begin{array}{l}-0.124 \\
(0.334)\end{array}$ & $\begin{array}{l}-0.005 \\
(0.027)\end{array}$ \\
\hline Age & $\begin{array}{r}-0.015 \\
(0.011)\end{array}$ & $\begin{array}{c}-0.002 \\
(0.001)\end{array}$ & $\begin{array}{l}-0.016 \\
(0.012)\end{array}$ & $\begin{array}{c}-0.001 \\
(0.001)\end{array}$ \\
\hline Education & $\begin{array}{l}0.369 \\
(0.243)\end{array}$ & $\begin{array}{c}0.046 \\
(0.030)\end{array}$ & $\begin{array}{c}0.216 \\
(0.243)\end{array}$ & $\begin{array}{l}0.014 \\
(0.020)\end{array}$ \\
\hline Income & $\begin{array}{l}0.157 \\
(0.271)\end{array}$ & $\begin{array}{c}0.018 \\
(0.034)\end{array}$ & $\begin{array}{c}0.223 \\
(0.263)\end{array}$ & $\begin{array}{l}0.018 \\
(0.022)\end{array}$ \\
\hline
\end{tabular}




\section{Attributes}

Years of experience

Organic

Cost-share Participation

USDA Programs

NRCS Programs

State Programs

Planned Future Adoption

Soil moisture sensors

Annual soil testing

Tissue testing

UF-IFAS Nutrient Recommendations

Impediments to Adoption

Costs of installation

Cannot finance
Plan A

\begin{tabular}{c}
\hline Coefficients \\
-0.013 \\
$(0.011)$ \\
$0.844^{* *}$ \\
$(0.407)$
\end{tabular}

Marginal effects

$-0.002$

(0.001)

$0.105^{* *}$

(0.049)

-0.276
$(0.504)$
0.371
$(0.311)$
0.145
$(0.274)$

$-0.030$

(0.055)

0.052

(0.044)

0.008

(0.034)

$0.702^{* * *}$
$(0.281)$
-0.086
$(0.291)$
0.383
$(0.338)$
0.298
$(0.344)$

$0.104^{* *}$

(0.044)

$-0.004$

(0.036)

0.044

(0.046)

0.030

(0.045)

\subsection{5}

(0.308)

0.439

(0.281)
Plan B

\begin{tabular}{cc}
\hline Coefficients & Marginal effects \\
0.0002 & 0.0002 \\
$(0.011)$ & $(0.0009)$ \\
0.555 & 0.038 \\
$(0.579)$ & $(0.050)$ \\
& \\
-0.348 & -0.025 \\
$(0.581)$ & $(0.040)$ \\
0.062 & -0.001 \\
$(0.306)$ & $(0.025)$ \\
$0.626^{* *}$ & $0.060^{* *}$ \\
$(0.264)$ & $(0.025)$ \\
& \\
0.216 & 0.006 \\
$(0.296)$ & $(0.025)$ \\
$-0.525^{*}$ & $-0.044^{* *}$ \\
$(0.304)$ & $(0.021)$ \\
0.536 & 0.049 \\
$(0.312)$ & $(0.038)$ \\
$0.563^{*}$ & $0.055^{*}$ \\
$(0.351)$ & $(0.038)$ \\
& \\
0.367 & 0.030 \\
$(0.269)$ & $(0.021)$ \\
0.320 & 0.023 \\
$(0.268)$ & $(0.024)$ \\
\hline & \\
&
\end{tabular}




\section{Table 8. Continued}

\section{Attributes}

Might leave the ag. industry

Risk of reduced yield

Adoption takes too much time

Uncertainty about future water availability

Other reasons

Log likelihood

AIC

BIC
Plan A

Coefficients
-0.802
$(0.503)$
-0.611
$(0.532)$
-0.546
$(0.653)$
-0.203
$(0.778)$
-0.056
$(0.383)$

\section{Marginal effects}

$-0.078^{*}$

(0.045)

$-0.071$

(0.046)

$-0.062$

(0.057)

$-0.030$

(0.082)

$-0.007$

(0.047)
Plan B

\section{Coefficients}

$-1.247^{* *}$

(0.515)

0.114

(0.516)

$-0.065$

(0.557)

0.252

(0.580)

$-0.030$

(0.381)

$-1377.585$

2855.169

3187.316
Marginal effects

$-0.076^{* * *}$

(0.022)

0.020

(0.052)

0.002

(0.047)

0.030

(0.055)

$-0.002$

(0.031)

*** $1 \%$ significance level, **5\% significance level, ${ }^{*} 10 \%$ significance level with two-tailed tests.

Robust standard errors reported in parentheses. Range of marginal effects are provided for each attribute. For contracting agency, USDA is the base for the FDACS and FDEP marginal effects. 
Table 9. Test of Independence of Irrelevant Alternatives

\begin{tabular}{lcc}
\hline Alternative dropped & $\chi^{2}$ & Probability \\
\hline Plan A & 18.49 & 0.888 \\
Plan B & 34.60 & 0.149 \\
\hline
\end{tabular}

The third option (choosing neither Plan A nor B) was always the base. The null hypothesis is: $\mathrm{H}_{\mathrm{o}}$ : Difference in coefficients not systematic.

on the probability values, we fail to reject the null hypothesis. Therefore, there is no evidence that the IIA assumption is violated; implying that the conditional model is appropriate for the data, and the coefficient estimates are valid.

\section{Cost-Share Enrollment by Subsample}

To further investigate differential effects of factors affecting enrollment in costshare programs by type of respondent, we run the conditional logit for three subsamples from our dataset. First, we consider only respondents who have not yet adopted soil moisture sensors. Soil moisture sensors are the most expensive of the four practices of interest, so growers who have already adopted them may have little incentive to enroll in the hypothetical costshare program. Non-adoption of the program by this latter group may mask relationships found in the remaining subsample. Additionally, soil moisture sensors have the largest potential to reduce water use, so understanding viable ways to incentivize their adoption specifically is valuable.

The second group excludes respondents with only animal production. Animal production in Florida has a large impact on water quantity through direct consumption of water by livestock and on water quality through deposition of animal waste. The practices considered in the study, while applicable to animal producers, yield larger impacts on water use and runoff for crop production. A focus on waste management would yield larger impacts for animal producers and is outside the scope of this study. Given this contrast between crop and animal production, we are interested in how results might change if only focusing on producers of crops.

The third group includes only those who report irrigating their crops. While all crop producers could adopt soil and tissue testing and follow nutrient recommendations, soil moisture sensors are only relevant for those who irrigate their crops.

From Table 10, unlike the broader sample, it appears that respondents with no current soil moisture sensors are indifferent between FDACS and USDA as a contracting agency. Similar to the broader sample, this subgroup is 3.1-4.6 percent less likely to adopt if administered by FDEP compared to administration by USDA. The impact of contract length on this subgroup's hypothetical adoption is the same as the broader group of respondents. 
Table 10. Conditional Logit and Marginal Effects for Cost-Share Program Adoption for Respondents with No Current Soil Moisture Sensors $(\mathbf{N}=\mathbf{4 7 8})$

\begin{tabular}{|c|c|c|c|c|}
\hline Attributes & \multicolumn{2}{|c|}{ Coefficients } & \multicolumn{2}{|c|}{ Marginal effects } \\
\hline FDACS & \multicolumn{2}{|c|}{$\begin{array}{c}0.138 \\
(0.121)\end{array}$} & \multicolumn{2}{|c|}{$\begin{array}{c}0.013,0.019 \\
(0.011,0.017)\end{array}$} \\
\hline FDEP & \multicolumn{2}{|c|}{$\begin{array}{c}-0.361^{* *} \\
(0.146)\end{array}$} & \multicolumn{2}{|c|}{$\begin{array}{c}-0.046,-0.031^{* * *} \\
(0.002,0.012)\end{array}$} \\
\hline Length of contract (years) & \multicolumn{2}{|c|}{$\begin{array}{c}-0.080^{* * *} \\
(0.115)\end{array}$} & \multicolumn{2}{|c|}{$\begin{array}{c}-0.011,-0.007^{* * *} \\
(0.001,0.002)\end{array}$} \\
\hline On-farm visit & \multicolumn{2}{|c|}{$\begin{array}{l}-0.159 \\
(0.112)\end{array}$} & \multicolumn{2}{|c|}{$\begin{array}{c}-0.021,-0.015 \\
(0.011,0.015)\end{array}$} \\
\hline Initial + Annual Costs & \multicolumn{2}{|c|}{$\begin{array}{c}0.127 \\
(0.102)\end{array}$} & \multicolumn{2}{|c|}{$\begin{array}{c}0.012,0.017 \\
(0.009,0.014)\end{array}$} \\
\hline \multirow[t]{3}{*}{ Percent of costs covered } & \multicolumn{2}{|c|}{$\begin{array}{c}0.041^{* * *} \\
(0.004)\end{array}$} & \multicolumn{2}{|c|}{$\begin{array}{c}0.004,0.005^{* * *} \\
(0.0005,0.0006)\end{array}$} \\
\hline & \multicolumn{2}{|c|}{ Plan A } & \multicolumn{2}{|c|}{ Plan B } \\
\hline & Coefficients & Marginal effects & Coefficients & Marginal effects \\
\hline Acreage (100s) & $\begin{array}{c}0.020 \\
(0.010)\end{array}$ & $\begin{array}{l}0.002 \\
(0.002)\end{array}$ & $\begin{array}{c}-0.003 \\
(0.010)\end{array}$ & $\begin{array}{r}-0.0006 \\
(0.001)\end{array}$ \\
\hline Gender & $\begin{array}{l}-0.447 \\
(0.421)\end{array}$ & $\begin{array}{l}-0.052 \\
(0.042)\end{array}$ & $\begin{array}{c}-0.076 \\
(0.361)\end{array}$ & $\begin{array}{r}-0.0006 \\
(0.029)\end{array}$ \\
\hline Age & $\begin{array}{c}-0.020^{*} \\
(0.012)\end{array}$ & $\begin{array}{r}-0.002 * \\
(0.001)\end{array}$ & $\begin{array}{c}-0.027^{* *} \\
(0.013)\end{array}$ & $\begin{array}{c}-0.002^{* *} \\
(0.001)\end{array}$ \\
\hline Education & $\begin{array}{l}0.467^{*} \\
(0.269)\end{array}$ & $\begin{array}{c}0.056^{*} \\
(0.033)\end{array}$ & $\begin{array}{c}0.374 \\
(0.270)\end{array}$ & $\begin{array}{l}0.026 \\
(0.022)\end{array}$ \\
\hline
\end{tabular}




\section{Attributes}

Income

Years of experience

Organic

Cost-share Participation

USDA Programs

NRCS Programs

State Programs

Planned Future Adoption

Soil moisture sensors

Annual soil testing

Tissue testing

UF-IFAS Nutrient

Recommendations

Impediments to Adoption

Costs of installation
Plan A

\begin{tabular}{c}
\hline Coefficients \\
0.210 \\
$(0.300)$ \\
-0.011 \\
$(0.012)$ \\
0.678 \\
$(0.481)$
\end{tabular}

Marginal effects

0.024
$(0.037)$
-0.002
$(0.002)$
0.084
$(0.057)$

$-0.624$

(0.532)

$0.700^{* *}$

(0.330)

0.199

(0.305)

$-0.063$

(0.043)

$0.100^{* *}$

(0.049)

0.016

(0.038)

$\begin{array}{cl}0.884^{* * *} & 0.133^{* * *} \\ (0.317) & (0.051) \\ -0.040 & 0.002 \\ (0.308) & (0.038) \\ 0.409 & 0.051 \\ (0.379) & (0.053) \\ 0.245 & 0.024 \\ (0.370) & (0.048)\end{array}$

0.120

(0.309)
0.010

(0.038)
Plan B

\begin{tabular}{cc}
\multicolumn{2}{c}{ Plan B } \\
\hline Coefficients & Marginal effects \\
0.255 & 0.019 \\
$(0.292)$ & $(0.023)$ \\
0.006 & 0.0007 \\
$(0.012)$ & $(0.001)$ \\
0.429 & 0.028 \\
$(0.701)$ & $(0.058)$ \\
& \\
-0.652 & -0.042 \\
$(0.705)$ & $(0.039)$ \\
0.290 & 0.013 \\
$(0.341)$ & $(0.028)$ \\
$0.620^{* *}$ & $0.058^{* *}$ \\
$(0.296)$ & $(0.028)$ \\
& \\
0.319 & 0.011 \\
$(0.338)$ & $(0.028)$ \\
-0.511 & -0.042 \\
$(0.320)$ & $(0.022)$ \\
0.430 & 0.035 \\
$(0.377)$ & $(0.035)$ \\
0.515 & 0.049 \\
$(0.364)$ & $(0.038)$ \\
& \\
0.419 & 0.034 \\
$(0.297)$ & $(0.023)$ \\
\hline
\end{tabular}




\section{Table 10. Continued}

\begin{tabular}{|c|c|c|c|c|}
\hline \multirow[t]{2}{*}{ Attributes } & \multicolumn{2}{|c|}{ Plan A } & \multicolumn{2}{|c|}{ Plan B } \\
\hline & Coefficients & Marginal effects & Coefficients & Marginal effects \\
\hline Cannot finance & $\begin{array}{c}0.357 \\
(0.325)\end{array}$ & $\begin{array}{l}0.045 \\
(0.045)\end{array}$ & $\begin{array}{c}0.298 \\
(0.308)\end{array}$ & $\begin{array}{l}0.022 \\
(0.027)\end{array}$ \\
\hline Might leave the ag. industry & $\begin{array}{c}-0.881^{*} \\
(0.531)\end{array}$ & $\begin{array}{r}-0.084^{*} \\
(0.045)\end{array}$ & $\begin{array}{l}-1.311^{* *} \\
(0.586)\end{array}$ & $\begin{array}{c}-0.076^{* * *} \\
(0.024)\end{array}$ \\
\hline Risk of reduced yield & $\begin{array}{l}-0.594 \\
(0.546)\end{array}$ & $\begin{array}{l}-0.067 \\
(0.046)\end{array}$ & $\begin{array}{c}0.109 \\
(0.557)\end{array}$ & $\begin{array}{l}0.019 \\
(0.053)\end{array}$ \\
\hline Adoption takes too much time & $\begin{array}{l}-1.004 \\
(0.820)\end{array}$ & $\begin{array}{r}-0.095 \\
(0.052)\end{array}$ & $\begin{array}{c}-0.372 \\
(0.633)\end{array}$ & $\begin{array}{l}-0.020 \\
(0.044)\end{array}$ \\
\hline $\begin{array}{l}\text { Uncertainty about future water } \\
\text { availability }\end{array}$ & $\begin{array}{l}-0.605 \\
(0.927)\end{array}$ & $\begin{array}{l}-0.067 \\
(0.074)\end{array}$ & $\begin{array}{c}0.078 \\
(0.657)\end{array}$ & $\begin{array}{l}0.016 \\
(0.058)\end{array}$ \\
\hline Other reasons & $\begin{array}{l}-0.317 \\
(0.394)\end{array}$ & $\begin{array}{l}-0.034 \\
(0.043)\end{array}$ & $\begin{array}{c}-0.422 \\
(0.392)\end{array}$ & $\begin{array}{l}-0.030 \\
(0.026)\end{array}$ \\
\hline Log likelihood & & -11 & & \\
\hline AIC & & 246 & & \\
\hline BIC & & 279 & & \\
\hline
\end{tabular}

*** $1 \%$ significance level, $* * 5 \%$ significance level, $* 10 \%$ significance level with two-tailed tests.

Robust standard errors reported in parentheses. Range of marginal effects are provided for each attribute. For contracting agency, USDA is the base for the FDACS and FDEP marginal effects. 
Unlike the entire sample, they are indifferent to the kinds of costs covered by the agency, likely because the initial investment is the majority of total costs if the respondent has not yet adopted sensors. Although the kind of coverage matters less, the effects of the percent of costs covered is similar to the entire sample. The on-farm visit attribute is not significant for this subgroup, but the sign is the same as the entire sample. Regarding the respondent characteristics, in this subgroup, the age and the education level of the respondents significantly impact their probability of adoption; which was not the case with the entire sample (Table 8). There is a 0.02 percent decrease in the likelihood of adoption for each additional year of age and producers with a college degree are 5.6 percent more likely to adopt compared to those with a lower degree. For the farm characteristics, this subgroup shares some similarities with the entire sample; previous enrollment in state costshare programs positively impacts willingness to adopt. Looking at the implementation of the four practices of interest in the future, unlike in the broader sample where three out of four were significant, not surprisingly, only the (future) implementation of soil moisture sensors is significant and positive. This suggests that potential "early" adopters of cost-share programs from this subgroup could be the producers who already plan to install soil moisture sensors on their farms at some point in the next three years. This then calls into question the additionality of cost-share programs. If most who enroll would have adopted the practices anyway, there is a smaller incremental environmental impact.

Results from the model including only respondents with some crop acreage are in Table 11. Like the entire sample, all attributes' coefficients are significant except the "on-farm visit" attribute. All signs are as expected and discussed previously. The insignificance of the "on-farm visit" could suggest a difference between crop and animal producers in terms of willingness to accept on-farm monitoring. Just like with the broader sample, respondents in this subgroup who have enrolled in state-level cost-share programs in the past and/or plan to follow UF-IFAS nutrient recommendations in the future will be more likely to adopt new cost-share programs for BMP implementation. Additionally, certified-organic farm owners have an 11 percent increase in their likelihood of adoption and planning to adopt soil moisture sensors in the future also increases the probability of adoption by 10.3 percent for crop producers. A finding specific to this subgroup is that crop producers who think that adopting BMPs could reduce their yield would be 8 percent less likely to enroll in cost-share programs compared to those who do not have such belief.

Table 12 contains the results for the subsample of respondents who use irrigation. All program attribute signs are as previously discussed. Unlike the entire sample, our findings suggest that producers who irrigate are indifferent between FDEP and USDA as a contracting agent, but they are 3.86.4 percent more likely to enroll if administered by FDACS relative to administration by the USDA. Producers who irrigate may implicitly be more 
Table 11. Conditional Logit and Marginal Effects for Cost-Share Program Adoption for Crop Producers (Excluding Producers with Only Animal Production) $(\mathrm{N}=\mathbf{4 1 1})$

\begin{tabular}{|c|c|c|c|c|}
\hline Attributes & \multicolumn{2}{|c|}{ Coefficients } & \multicolumn{2}{|c|}{ Marginal effects } \\
\hline FDACS & \multicolumn{2}{|c|}{$\begin{array}{l}0.267^{* *} \\
(0.132)\end{array}$} & \multicolumn{2}{|c|}{$\begin{array}{l}0.024,0.038^{* *} \\
(0.013,0.019)\end{array}$} \\
\hline FDEP & \multicolumn{2}{|c|}{$\begin{array}{c}-0.325^{* *} \\
(0.160)\end{array}$} & \multicolumn{2}{|c|}{$\begin{array}{c}-0.043,-0.027^{* *} \\
(0.013,0.020)\end{array}$} \\
\hline Length of contract (years) & \multicolumn{2}{|c|}{$\begin{array}{c}-0.091^{* * *} \\
(0.015)\end{array}$} & \multicolumn{2}{|c|}{$\begin{array}{c}-0.012,-0.008^{* * *} \\
(0.001,0.002)\end{array}$} \\
\hline On-farm visit & \multicolumn{2}{|c|}{$\begin{array}{l}-0.124 \\
(0.120)\end{array}$} & \multicolumn{2}{|c|}{$\begin{array}{c}-0.017,-0.011 \\
(0.011,0.017)\end{array}$} \\
\hline Initial + Annual Costs & \multicolumn{2}{|c|}{$\begin{array}{c}0.203^{*} \\
(0.111)\end{array}$} & \multicolumn{2}{|c|}{$\begin{array}{c}0.018,0.028^{*} \\
(0.010,0.015)\end{array}$} \\
\hline \multirow[t]{3}{*}{ Percent of costs covered } & \multicolumn{2}{|c|}{$\begin{array}{l}0.046^{* * *} \\
(0.004)\end{array}$} & \multicolumn{2}{|c|}{$\begin{array}{c}0.004,0.006^{* * *} \\
(0.0005,0.0006)\end{array}$} \\
\hline & \multicolumn{2}{|c|}{ Plan A } & \multicolumn{2}{|c|}{ Plan B } \\
\hline & Coefficients & Marginal effects & Coefficients & Marginal effects \\
\hline Acreage (100s) & $\begin{array}{l}0.002 \\
(0.010)\end{array}$ & $\begin{array}{l}0.0005 \\
(0.001)\end{array}$ & $\begin{array}{l}-0.010 \\
(0.010)\end{array}$ & $\begin{array}{r}-0.0009 \\
(0.001)\end{array}$ \\
\hline Gender & $\begin{array}{l}-0.190 \\
(0.458)\end{array}$ & $\begin{array}{l}-0.023 \\
(0.053)\end{array}$ & $\begin{array}{l}-0.090 \\
(0.417)\end{array}$ & $\begin{array}{c}-0.005 \\
(0.032)\end{array}$ \\
\hline Age & $\begin{array}{c}-0.008 \\
(0.013)\end{array}$ & $\begin{array}{l}-0.001 \\
(0.002)\end{array}$ & $\begin{array}{c}-0.014 \\
(0.016)\end{array}$ & $\begin{array}{c}-0.001 \\
(0.001)\end{array}$ \\
\hline Education & $\begin{array}{l}0.304 \\
(0.278)\end{array}$ & $\begin{array}{l}0.039 \\
(0.035)\end{array}$ & $\begin{array}{c}0.178 \\
(0.285)\end{array}$ & $\begin{array}{l}0.011 \\
(0.022)\end{array}$ \\
\hline Income & $\begin{array}{l}0.253 \\
(0.290)\end{array}$ & $\begin{array}{l}0.028 \\
(0.037)\end{array}$ & $\begin{array}{c}0.406 \\
(0.302)\end{array}$ & $\begin{array}{l}0.032 \\
(0.024)\end{array}$ \\
\hline
\end{tabular}




\section{Attributes}

Years of experience

Organic

\section{Cost-share Participation}

USDA Programs

NRCS Programs

State Programs

Planned Future Adoption

Soil moisture sensors

Annual soil testing

Tissue testing

UF-IFAS Nutrient Recommendations

Impediments to Adoption

Costs of installation

Cannot finance

Plan A

\section{Coefficients}

$-0.009$

(0.012)

$0.893^{* *}$

(0.391)

0.065

(0.509)

0.381

(0.350)

0.101

(0.307)

$$
\begin{gathered}
0.687^{* *} \\
(0.305) \\
-0.348 \\
(0.346) \\
0.126 \\
(0.347) \\
0.376 \\
(0.371)
\end{gathered}
$$

0.121

(0.326)

0.438

(0.313)
Marginal effects

$-0.001$

(0.002)

$0.110^{* *}$

(0.047)

0.010

(0.065)

0.052

(0.049)

0.003

(0.038)

$0.103^{* *}$

(0.048)

$-0.035$

(0.040)

0.012

(0.043)

\begin{tabular}{|c|c|}
\hline Coefficients & Marginal effects \\
\hline $\begin{array}{c}0.006 \\
(0.013)\end{array}$ & $\begin{array}{r}0.0007 \\
(0.001)\end{array}$ \\
\hline $\begin{array}{c}0.733 \\
(0.567)\end{array}$ & $\begin{array}{l}0.050 \\
(0.046)\end{array}$ \\
\hline
\end{tabular}

0.032

(0.049)

0.013

(0.041)

0.055

(0.044)
Plan B

$-0.037$

(0.626)

$-0.004$

(0.047)

0.170

(0.348)

0.632 **

(0.300)

0.009

(0.027)

$0.058^{* *}$

(0.026)

\subsection{1}

(0.346)

0.003

(0.026)

$-0.771^{* *}$

(0.367)

$-0.055^{* *}$

(0.022)

0.029

(0.038)

(0.411)

$0.102^{* *}$

$0.962^{* *}$

(0.408)

(0.051)

$\begin{array}{cl}0.205 & 0.016 \\ (0.286) & (0.022) \\ 0.419 & 0.031 \\ (0.292) & (0.025)\end{array}$




\section{Table 11. Continued}

\begin{tabular}{|c|c|c|c|c|}
\hline \multirow[t]{2}{*}{ Attributes } & \multicolumn{2}{|c|}{ Plan A } & \multicolumn{2}{|c|}{ Plan B } \\
\hline & Coefficients & Marginal effects & Coefficients & Marginal effects \\
\hline Might leave the ag. Industry & $\begin{array}{c}-1.287^{* * *} \\
(0.525)\end{array}$ & $\begin{array}{c}-0.119^{* * *} \\
(0.036)\end{array}$ & $\begin{array}{c}-1.252^{* *} \\
(0.586)\end{array}$ & $\begin{array}{c}-0.069 * * * \\
(0.024)\end{array}$ \\
\hline Risk of reduced yield & $\begin{array}{l}-0.674 \\
(0.573)\end{array}$ & $\begin{array}{r}-0.080^{*} \\
(0.047)\end{array}$ & $\begin{array}{c}0.357 \\
(0.543)\end{array}$ & $\begin{array}{l}0.047 \\
(0.060)\end{array}$ \\
\hline Adoption takes too much time & $\begin{array}{l}-0.514 \\
(0.715)\end{array}$ & $\begin{array}{l}-0.054 \\
(0.069)\end{array}$ & $\begin{array}{l}-0.677 \\
(0.661)\end{array}$ & $\begin{array}{c}-0.042 \\
(0.033)\end{array}$ \\
\hline Uncertainty about future water availability & $\begin{array}{l}-0.021 \\
(0.799)\end{array}$ & $\begin{array}{l}-0.016 \\
(0.089)\end{array}$ & $\begin{array}{c}0.641 \\
(0.636)\end{array}$ & $\begin{array}{l}0.071 \\
(0.070)\end{array}$ \\
\hline Other reasons & $\begin{array}{l}0.148 \\
(0.428)\end{array}$ & $\begin{array}{l}0.016 \\
(0.056)\end{array}$ & $\begin{array}{c}0.276 \\
(0.432)\end{array}$ & $\begin{array}{l}0.024 \\
(0.038)\end{array}$ \\
\hline Log likelihood & \multicolumn{4}{|c|}{-1056.565} \\
\hline AIC & \multicolumn{4}{|c|}{2213.130} \\
\hline BIC & \multicolumn{4}{|c|}{2532.711} \\
\hline
\end{tabular}

*** $1 \%$ significance level, $* * 5 \%$ significance level, $* 10 \%$ significance level with two-tailed tests.

Robust standard errors reported in parentheses. Range of marginal effects are provided for each attribute. For contracting agency, USDA is the base for the FDACS and FDEP marginal effects. 
Table 12. Conditional logit and marginal effects for cost-share program adoption for producers who currently irrigate ( $\mathrm{N}=\mathbf{2 9 9})$

\begin{tabular}{|c|c|c|c|c|}
\hline Attributes & \multicolumn{2}{|c|}{ Coefficients } & \multicolumn{2}{|c|}{ Marginal effects } \\
\hline FDACS & \multicolumn{2}{|c|}{$\begin{array}{c}0.468^{* * *} \\
(0.156)\end{array}$} & \multicolumn{2}{|c|}{$\begin{array}{c}0.038,0.064^{* * *} \\
(0.015,0.023)\end{array}$} \\
\hline FDEP & \multicolumn{2}{|c|}{$\begin{array}{l}-0.153 \\
(0.207)\end{array}$} & \multicolumn{2}{|c|}{$\begin{array}{c}-0.019,-0.011 \\
(0.015,0.026)\end{array}$} \\
\hline Length of contract (years) & \multicolumn{2}{|c|}{$\begin{array}{c}-0.099^{* * *} \\
(0.018)\end{array}$} & \multicolumn{2}{|c|}{$\begin{array}{c}-0.013,-0.008^{* * *} \\
(0.001,0.002)\end{array}$} \\
\hline On-farm visit & \multicolumn{2}{|c|}{$\begin{array}{l}-0.138 \\
(0.139)\end{array}$} & \multicolumn{2}{|c|}{$\begin{array}{c}-0.018,-0.011 \\
(0.011,0.018)\end{array}$} \\
\hline Initial + Annual Costs & \multicolumn{2}{|c|}{$\begin{array}{c}0.216^{*} \\
(0.134)\end{array}$} & \multicolumn{2}{|c|}{$\begin{array}{c}0.017,0.028^{*} \\
(0.011,0.017)\end{array}$} \\
\hline \multirow[t]{3}{*}{ Percent of costs covered } & \multicolumn{2}{|c|}{$\begin{array}{c}0.049^{* * *} \\
(0.005)\end{array}$} & \multicolumn{2}{|c|}{$\begin{array}{c}0.004,0.006^{* * *} \\
(0.0006,0.0008)\end{array}$} \\
\hline & \multicolumn{2}{|c|}{ Plan A } & \multicolumn{2}{|c|}{ Plan B } \\
\hline & Coefficients & Marginal effects & Coefficients & Marginal effects \\
\hline Acreage (100s) & $\begin{array}{c}-0.020 \\
(0.010)\end{array}$ & $\begin{array}{c}-0.003 \\
(0.001)\end{array}$ & $\begin{array}{l}-0.020 \\
(0.010)\end{array}$ & $\begin{array}{l}-0.001 \\
(0.0008)\end{array}$ \\
\hline Gender & $\begin{array}{c}-1.024^{* *} \\
(0.490)\end{array}$ & $\begin{array}{c}-0.096^{* * *} \\
(0.035)\end{array}$ & $\begin{array}{l}-0.247 \\
(0.522)\end{array}$ & $\begin{array}{l}-0.009 \\
(0.035)\end{array}$ \\
\hline Age & $\begin{array}{r}-0.030^{*} \\
(0.016)\end{array}$ & $\begin{array}{r}-0.004^{*} \\
(0.002)\end{array}$ & $\begin{array}{l}-0.026 \\
(0.020)\end{array}$ & $\begin{array}{l}-0.002 \\
(0.001)\end{array}$ \\
\hline Education & $\begin{array}{c}-0.288 \\
(0.336)\end{array}$ & $\begin{array}{c}-0.035 \\
(0.041)\end{array}$ & $\begin{array}{l}-0.176 \\
(0.351)\end{array}$ & $\begin{array}{c}-0.010 \\
(0.025)\end{array}$ \\
\hline
\end{tabular}


Table 12. Continued

\begin{tabular}{|c|c|c|c|c|}
\hline \multirow[t]{2}{*}{ Attributes } & \multicolumn{2}{|c|}{ Plan A } & \multicolumn{2}{|c|}{ Plan B } \\
\hline & Coefficients & Marginal effects & Coefficients & Marginal effects \\
\hline Income & $\begin{array}{l}0.266 \\
(0.349)\end{array}$ & $\begin{array}{l}0.034 \\
(0.044)\end{array}$ & $\begin{array}{l}0.234 \\
(0.294)\end{array}$ & $\begin{array}{l}0.005 \\
(0.024)\end{array}$ \\
\hline Years of experience & $\begin{array}{r}-0.023^{*} \\
(0.014)\end{array}$ & $\begin{array}{r}-0.003^{*} \\
(0.002)\end{array}$ & $\begin{array}{l}-0.012 \\
(0.015)\end{array}$ & $\begin{array}{r}-0.0006 \\
(0.001)\end{array}$ \\
\hline Organic & $\begin{array}{l}1.602^{* * *} \\
(0.568)\end{array}$ & $\begin{array}{l}0.185^{* * *} \\
(0.065)\end{array}$ & $\begin{array}{l}1.678 \text { *** } \\
(0.614)\end{array}$ & $\begin{array}{l}0.108^{* * *} \\
(0.042)\end{array}$ \\
\hline \multicolumn{5}{|l|}{ Cost-share Participation } \\
\hline USDA Programs & $\begin{array}{c}-0.191 \\
(0.651)\end{array}$ & $\begin{array}{c}-0.024 \\
(0.067)\end{array}$ & $\begin{array}{l}0.096 \\
(0.752)\end{array}$ & $\begin{array}{l}0.010 \\
(0.057)\end{array}$ \\
\hline NRCS Programs & $\begin{array}{l}0.318 \\
(0.519)\end{array}$ & $\begin{array}{l}0.036 \\
(0.065)\end{array}$ & $\begin{array}{l}0.457 \\
(0.479)\end{array}$ & $\begin{array}{l}0.034 \\
(0.039)\end{array}$ \\
\hline State Programs & $\begin{array}{l}0.369 \\
(0.358)\end{array}$ & $\begin{array}{l}0.039 \\
(0.044)\end{array}$ & $\begin{array}{l}0.677^{*} \\
(0.378)\end{array}$ & $\begin{array}{l}0.050^{*} \\
(0.029)\end{array}$ \\
\hline \multicolumn{5}{|l|}{ Planned Future Adoption } \\
\hline Soil moisture sensors & $\begin{array}{l}0.515 \\
(0.340)\end{array}$ & $\begin{array}{l}0.072 \\
(0.047)\end{array}$ & $\begin{array}{c}-0.039 \\
(0.375)\end{array}$ & $\begin{array}{c}-0.010 \\
(0.024)\end{array}$ \\
\hline Annual soil testing & $\begin{array}{l}0.027 \\
(0.408)\end{array}$ & $\begin{array}{l}0.007 \\
(0.050)\end{array}$ & $\begin{array}{l}-0.321 \\
(0.467)\end{array}$ & $\begin{array}{c}-0.023 \\
(0.028)\end{array}$ \\
\hline Tissue testing & $\begin{array}{l}0.141 \\
(0.417)\end{array}$ & $\begin{array}{l}0.015 \\
(0.052)\end{array}$ & $\begin{array}{l}0.240 \\
(0.509)\end{array}$ & $\begin{array}{l}0.018 \\
(0.040)\end{array}$ \\
\hline UF-IFAS Nutrient Recommendations & $\begin{array}{l}0.842^{*} \\
(0.510)\end{array}$ & $\begin{array}{l}0.106 \\
(0.078)\end{array}$ & $\begin{array}{l}1.032^{*} \\
(0.559)\end{array}$ & $\begin{array}{l}0.085 \\
(0.058)\end{array}$ \\
\hline \multicolumn{5}{|l|}{ Impediments to Adoption } \\
\hline Costs of installation & $\begin{array}{l}0.443 \\
(0.430)\end{array}$ & $\begin{array}{l}0.049 \\
(0.046)\end{array}$ & $\begin{array}{l}0.446 \\
(0.384)\end{array}$ & $\begin{array}{l}0.027 \\
(0.024)\end{array}$ \\
\hline
\end{tabular}




\section{Attributes}

Cannot finance

Might leave the ag. Industry

Risk of reduced yield

Adoption takes too much time

Uncertainty about future water availability

Other reasons

\begin{tabular}{c} 
\\
\hline Coefficients \\
0.537 \\
$(0.382)$ \\
-0.716 \\
$(0.619)$ \\
-0.009 \\
$(0.591)$ \\
$-1.347^{* *}$ \\
$(0.601)$ \\
$-1.731^{*}$ \\
$(0.950)$ \\
0.306 \\
$(0.504)$
\end{tabular}

Plan A

Marginal effects

0.075

(0.054)

$-0.069$

(0.053)

$-0.001$

(0.071)

$-0.109^{* * *}$

(0.035)

$-0.123^{* * *}$

(0.035)

0.029

$(0.063)$
Plan B

\begin{tabular}{cc}
\hline Coefficients & Marginal effects \\
0.027 & -0.005 \\
$(0.364)$ & $(0.023)$ \\
$-1.052^{*}$ & $-0.054^{* *}$ \\
$(0.587)$ & $(0.023)$ \\
-0.012 & -0.0008 \\
$(0.779)$ & $(0.056)$ \\
-0.865 & -0.042 \\
$(0.988)$ & $(0.041)$ \\
-1.022 & -0.047 \\
$(0.884)$ & $(0.033)$ \\
0.722 & 0.063 \\
$(0.515)$ & $(0.052)$ \\
26 & \\
2 & \\
96 &
\end{tabular}

Log likelihood

$-707.156$

1514.312

1817.069

*** $1 \%$ significance level, $* * 5 \%$ significance level, $* 10 \%$ significance level with two-tailed tests.

Robust standard errors reported in parentheses. Range of marginal effects are provided for each attribute. For contracting agency, USDA is the base for the FDACS and FDEP marginal effects. 
environmentally aware due to their dependence on external sources of water. Age and years of experience have significant negative effects on the probability of adoption among irrigators, while holding an organic certification has an increase adoption by 18.5 percent. Female irrigators are 9.6 percent less likely to adopt cost-share programs compared to male irrigators. Specific to this subgroup, irrigators who have an uncertainty about the availability of water in the future and/or believe that adoption of BMPs takes too much time are 12.3 percent and 10.9 percent less likely to adopt, respectively, than those who do not share the same belief and/or uncertainty.

Regardless of the subsamples being targeted, producers who have adopted any state-level cost-share programs in the past are more likely to enroll in new ones to implement more BMPs. This latter result suggests that current state-run cost-share programs are well implemented and seen as beneficial to those who use them.

\section{Conclusion}

This article investigates cost-share program attributes that would affect producers' willingness to enroll in these programs. Increasing adoption of best management practices (BMPs) would ensure improvements in water quality and more efficient usage of water. Cost-share programs are used as a form of payment for ecosystems services to encourage adoption of BMPs.

Our results indicate that cost-share programs implemented by state-level departments of agriculture as opposed to federal-level or environmentally focused agencies could result in higher rates of cost-share enrollment and adoption of BMPs. This finding is important given the wide range of possible agri-environmental schemes that could be implemented by any kind of agency. For example, the Florida legislature is currently considering a voluntary program in which agricultural producers could receive tax credits for carbon farming (Rodriguez 2020). The current draft of the bill charges the Florida Department of Environmental Protection with implementation. Farmers may be more likely to enroll if the Florida Department of Agricultural and Consumer Services implements the program.

While self-reporting increases rates of enrollment compared to on-farm visits, it also allows for lower compliance. Similarly, shorter contracts increase enrollment but may lessen long-term environmental impacts of the program. Contracts with a higher percent of costs covered also increase enrollment rates, as would be expected, but increasing coverage by one percentage point increases the probability of adoption by less than one percent. Our results suggest that a substantial portion (43.62\%) would never enroll in such a cost-share program within the range of coverage considered here. It appears that younger male farmers with a college degree who have recently entered the agriculture industry would be the group most likely to adopt cost-share programs. 
Our findings suggest that to increase enrollment, cost-share programs could be tailored to the needs of each kind of producer. For producers who are not currently using soil moisture sensors on their farms, they would be more likely to enroll in new cost-share programs if they have already adopted some state-level cost-share programs in the past; i.e., they will be willing to enroll in new programs to complement the ones they already have. Policymakers could design cost-share programs that simply expand the ones currently offered at the state level to reduce additional application costs (in terms of time) to take advantage of this perceived complementarity. For crop (as opposed to animal) producers, extensions agents could provide them with information demonstrating that BMPs do not increase the risk of yield reductions.

For irrigators, the belief that adoption of BMPs takes too much time and the uncertainty about water availability in the future appear to be the primary constraints for enrollment in cost-share programs. Adoption of BMPs will ensure efficient use of water, and collective adoption of BMPs will reduce uncertainty of future water availability. Therefore, education and trainings are needed to instill confidence in this subgroup that BMPs are effective, efficient, and will improve water availability in the long run. Cost-share programs could also include technical support after enrollment to ensure that new adopters have all the guidance and the support needed to efficiently and effectively undertake BMPs.

While the results provide insights for ways to increase enrollment in costshare programs and consequently increase adoption of BMPs, some of the results call into question the magnitude of the potential effect on the environment. For example, producers who stated early on in the survey that they planned to adopt soil moisture sensors in the next three years were more likely to indicate that they would enroll in the hypothetical cost-share programs. This could imply that cost-share programs would subsidize at least some producers who still would have adopted the practices in the absence of the program. Previous literature finds additionality rates of 68 to 98 percent for water conservation and nutrient reduction practices, with higher additionality occurring for more expensive practices (Claassen, Duquette, and Smith 2018). Only 18 percent of our sample indicated that they plan to adopt soil moisture sensors in the next three years, suggesting that the predicted additionality could be similar to previous literature. Similarly, program attributes that would likely create larger impacts on the environment (onfarm visits for monitoring and longer-term contracts) are associated with lower probabilities of adoption.

Overall, the results here signal challenges and opportunities in terms of reaching long-term environmental goals. Any increase in adoption of BMPs will move the areas closer to their water quality and water conservation goals. Farmers seem more comfortable to enroll with trusted local agencies. Policymakers could design short-term contracts as a starting point to enroll more participants and then offer incentives to renew enrollment by working 
with local contracting agencies. Further research is needed to determine the net effects of each attribute on observed BMP adoption rates over time, which may differ from stated adoption rates.

\section{Funding Statement}

This research was funded by USDA National Institute of Food and Agriculture National Integrated Water Quality Program Award No. 2014-51130-22495.

\section{Supplementary material}

The supplementary material for this article can be found at https://doi.org/10. $1017 /$ age. 2020.5

\section{References}

Alcon, F., S. Tapsuwan, R. Brouwer, and M.D. Miguel. 2014. "A Choice Experiment of Farmer's Acceptance and Adoption of Irrigation Water Supply Management Policies." EAAE 1-12.

Barton, D.N., and O. Bergland. 2010. "Valuing Irrigation Water Using a Choice Experiment: An Individual Status Quo Modelling of Farm Specific Water Scarcity." Environment and Development Economics 15(3): 321-340.

Bellino, J.C. 2017. "Groundwater Withdrawals in Florida and Parts of Georgia, Alabama, and South Carolina, 1995-2010." Available at: https://www.sciencebase.gov/catalog/item/ 56b11823e4b07a81bb233756 (accessed April 2019).

Claassen, R., E.N. Duquette, and D.J. Smith. 2018. "Additionality in U.S. Agricultural Conservation Programs." Land Economics 94(1): 19-35.

Dieter, C.A., M.A. Maupin, R.R. Caldwell, M.A. Harris, T.I. Ivahnenko, J.K. Lovelace, and K.S. Linsey. 2018. "Estimated Use of Water in the United States in 2015." Available at: https://pubs.usgs.gov/circ/1441/circ1441.pdf (accessed April 2019).

FDACS. 2017. "Estimated Agricultural Water Demand 2015-2040." Available at: https:// www.freshfromflorida.com/content/download/78207/2313146/ FSAID_IV_Water_Use_Estimates_06.23.2017.pdf (accessed March 2019).

FDEP. 2011. "Florida Water Resource Caution Areas (WRCA)." Available at: https://geodata. dep.state.fl.us/datasets/f51b88085e5e4e6f892dda74eedd4789_0 (accessed March 2019).

— 2018. "Basin Management Action Plans (BMAPs)." Available: https://floridadep.gov/ dear/water-quality-restoration/content/basin-management-action-plans-bmaps (accessed January 2019)

Horne, P. 2006. "Forest Owners' Acceptance of Incentive-Based Policy Instruments in Forest Biodiversity Conservation - a Choice Experiment Based Approach." Silva Fennica 40(1): 169-178.

Kreye, M.M., E.F. Pienaar, and A.E. Adams. 2017. "The Role of Community Identity in Cattleman Response to Florida Panther Recovery Efforts." Society \& Natural Resources 30(1): 79-94.

Liu, T., R.J.F. Bruins, and M.T. Heberling. 2018. "Factors Influencing Farmers' Adoption of Best Management Practices: A Review and Synthesis." Sustainability (Switzerland) 10(2): 1-26.

Marella, R.L. 2014. "Water Withdrawals, Use, and Trends in Florida, 2010." Available at: https://doi.org/http://dx.doi.org/10.3133/sir20145088 (accessed April 2019). 
Marella, R.L., and M. Berndt. 2005. "Water Withdrawals and Trends from the Floridan Aquifer System in the Southeastern United States, 1950-2000." Available at: http://www.usgs. gov/ (accessed February 2019).

Marella, R.L., and J.F. Dixon. 2018. "Data tables Summarizing the Source-Specific Estimated Water Withdrawals in Florida by Category, County, and Water Management District, 2015." Available at: https://www.sciencebase.gov/catalog/item/5a4cdec8e4b0d05ee8c4cabf (accessed April 2019).

McFadden, D. 1974. "Conditional logit analysis of qualitative choice behavior." In P. Zarembka (Ed.), Frontiers in Econometrics (pp. 105-142). New York: Academic Press.

Mercadé, L., J.M. Gil, Z. Kallas, and J. Serra. 2009. "A Choice Experiment Method to Assess Vegetables Producers' Preferences for Crop Insurance." EAAE 1-12.

Milleson, M.L., S.A. Shwiff, and M.L. Avery. 2006. "Vulture-Cattle Interactions: A Survey of Florida Ranchers." In Research Perspectives: Proceedings of the Vertebrate Pest Conference, UC Agriculture \& Natural Resources. Davis, CA.

Odera, E., A. Lamm, M. Dukes, T. Irani, and H. Carter. 2013. "Water Issues in Florida: How Extension Can Facilitate Stakeholder Engagement and Involvement." Available at: http://www.dep.state.fl.us/water/waterpolicy/districts.htm (accessed February 2019).

Paxton, K.W., A.K. Mishra, S. Chintawar, R.K. Roland, J.A. Larson, B.C. English, D.M. Lambert, M. C. Marra, S.L. Larkin, J.M. Reeves, and S.W. Martin. 2011. "Intensity of Precision Agriculture Technology Adoption by Cotton Producers." Agricultural and Resource Economics Review 40(1): 133-144.

Prokopy, L.S., K. Floress, D. Klotthor-Weinkauf, and A. Baumgart-Getz. 2008. "Determinants of Agricultural Best Management Practice Adoption: Evidence from the Literature." Journal of Soil and Water Conservation 63(5): 300-311.

Qin, P., F. Carlsson, and J. Xu. 2009. "Forestland Reform in China: What Do the Farmers Want? A Choice Experiment on Farmers' Property Rights Preferences." Working Papers in Economics 370, University of Gothenburg, Department of Economics.

Rodriguez, J.J. 2020. "An Act Relating to the Tax Credit for Carbon Farming." Florida Senate SB 286.

Saldias, C., S. Speelman, G. Van Huylenbroeck, and N. Vink. 2016. “Understanding Farmers' Preferences for Wastewater Reuse Frameworks in Agricultural Irrigation: Lessons from a Choice Experiment in the Western Cape, South Africa." Water SA 42(1): 26-37.

Schaible, G.D., and M.P. Aillery. 2012. United States Department of Agriculture, Economic Research Service, "Water Conservation in Irrigated Agriculture: Trends and Challenges in the Face of Emerging Demands." Available at: http://www.ers.usda.gov (accessed April 2019).

United States Department of Agriculture [USDA]. 2017. Census of Agriculture, Volume 1, Chapter 1, State Level Data. Available: https://www.nass.usda.gov/Publications/ AgCensus/2017/Full_Report/Volume_1,_Chapter_1_State_Level/Florida/_ (accessed December 2019).

United States Department of Agriculture [USDA]. 2018. Census of Agriculture, Quick Stats. Available: https://quickstats.nass.usda.gov/ (accessed December 2019).

van Dijl, E.A., K.A. Grogan, and T. Borisova. 2015. "Determinants of Adoption of Drought Adaptations among Vegetable Growers in Florida." Journal of Soil and Water Conservation 70(4): 218-231.

Zotarell, L., M.D. Dukes, and M. Paranhos. 2013. "Minimum Number of Soil Moisture Sensors for Monitoring and Irrigation Purposes." University of Florida Extension EDIS Document HS1222. 